\title{
Sports education an element of academic development
}

\section{La educación deportiva un elemento de desarrollo académico}

\author{
MORALES-BENÍTEZ, Brenda Ivonne†*, MORALES-HERNÁNDEZ, Ramiro and ALCARAZ- \\ GONZÁLEZ, Ramsés Josafath
}

Universidad Autónoma de Guerrero, México.

ID $1^{\text {st }}$ Author: Brenda Ivonne, Morales-Benítez / ORC ID: 0000-0002-0309-3885

ID $1^{\text {st }}$ Coauthor: Ramiro, Morales-Hernández / ORC ID: 0000-0003-0510-8793

ID $2^{\text {nd }}$ Coauthor: Ramsés Josafath, Alcaraz-González

DOI: $10.35429 /$ EJS.2020.13.7.1.6

Received: July 15, 2020; Accepted: December 10, 2020

\begin{abstract}
Sport is regularly seen as one of the forms of activation of the body that provide motor skills and contribute to healthy health, however it is important to appreciate it from the point of view of knowledge, so its contribution in aspects of academic competencies in students was analyzed upper middle level. In the first part, the history of sport was discussed, as well as the contributions of authors about educational sport and the learning generated. Subsequently, a comparison was made in young upper-middle-level students divided into two groups: the experiential group (they practice and perform exercise, sport and physical activity) and the control group (individuals who are totally sedentary), in order to observe performance. in school performance, class participation, decision making as well as knowing how influential or manipulable their peers can be to analyze and solve problems, in the study a questionnaire was applied to both groups using the Likert scale to know these results. The information obtained shows the positive influence that sport has on the development of educational capacities in students.
\end{abstract}

Educational sport, Academic performance, Cognitive process, Students

\section{Resumen}

El deporte regularmente es visto como una de las formas de activación del cuerpo que aportan motricidad y coadyuvan a tener una sana salud, sin embargo, es importante apreciarlo desde la óptica del conocimiento, por lo que se analizó su contribución en aspectos de competencias académicas en estudiantes de nivel medio superior. En la primera parte se abordó la historia del deporte, así como las contribuciones de autores en referencia al deporte educativo y los aprendizajes generados. posteriormente se efectúo un comparativo en jóvenes estudiantes de nivel medio superior divididos en dos grupos: el grupo experimental (practican y realizan ejercicio, deporte y actividad física) y el grupo control (individuos que son totalmente sedentarios), con la finalidad de observar el desempeño en el rendimiento escolar, la participación en clases, la toma de decisiones así como también conocer lo influenciable o manipulables que pueden ser por sus compañeros para analizar y resolver problemas, en el estudio se aplicó un cuestionario a los dos grupos utilizando la escala de Likert para conocer estos resultados. La información obtenida muestra la influencia positiva que tiene el deporte en el desarrollo de capacidades educativas en los estudiantes.

Deporte educativo, Rendimiento académico, Proceso cognitivo, Estudiantes

Citation: MORALES-BENÍTEZ, Brenda Ivonne, MORALES-HERNÁNDEZ, Ramiro and ALCARAZ-GONZÁLEZ, Ramsés Josafath. Sports education an element of academic development. ECORFAN Journal-Spain. 2020. 7-13: 1-6.

\footnotetext{
* Correspondence to Author (Email: ivonne483@gmail.com)

$\dagger$ Researcher contributing as first author.
} 


\section{Introduction}

Since ancient times sport has been part of the education and culture of men, where history accounts for it, grouping them into five significant stages: the Cultural or non-agonal game practiced in the prehistoric period, during the protohistory part of the antiquity and until the beginning of the Olympic Games (776 BC), Agonistic Game carried out from the Olympic Games and its term was with the beginning of the Amateur sport when the Olympic Games of the modern era was established (776 BC - 1896), Media Sports where the media are involved, that is, they were the first to be broadcast on television (German Olympic Games 1936), and the last stage was Professional Sports at the 1932 Barcelona Olympic Games where the "Dream Team ”(Hernández and Recoder 2015).

Due to the importance and efficiency of physical activity and sport, it is incorporated into school spaces from the basic levels as one of the activities and / or subjects that the student must take; because working at an early age allows the development of motor, cognitive and affective skills; according to Blázquez (1995), educational sport is fundamental in harmonious development and in the strengthening of values; which has two important senses, the first one where the physical practices that are developed within educational institutions are circumscribed and the second one the activities practiced at school age not established in school but, its execution must be subject to an educational and formative orientation even when it is developed outside the school institution. Authors such as Ruíz and Cabrera (2004), agree that physical exercise leads to improvements in educational processes, as well as in the development of social and individual values.

There are various studies that show that practicing a sport favors cognitive and personality processes in individuals, compared to those who are sedentary, and those who perform physical activity have better levels of health, better attitudes, discipline, enthusiasm and better academic performance against those who do not perform any physical activity (Linder 2002; Ramírez, Vinaccia \& Suárez, 2004).

\section{The sport educational element of the individual}

Educational sport has its origins in England in the 19th century, where only male children of the upper class of society had access to clubs and schools to educate themselves (Mandell, 1986; Hernández Moreno, 1995; Barbero González, 1993; Bordieu , 1993; Sampedro, 1996), the evolutionary development of games and hobbies taught in these institutions begins what we recognize as sport. Elias N. (1992), mentions that the root of sport is generated by the link between the development of the power structure in eighteenth-century England and the way in which entertainment and social games that were incorporated were progressing. to the characteristics of what we see today as a sport.

The transcendence of sports education should be seen with a comprehensive perspective and not only as technical and physical learning as traditionally observed, so it must also be perceived from the point of view of the improvement in the transformation processes that the individual acquires when practicing it, as it is, greater participation, decision making and defending their ideas against social problems (less influenceable), in addition to improving cognitive processes.

Feu (2000), affirms that in order for sport to contribute to the formation and education of the individual, it must assume a series of characteristics, among which are promoting personal autonomy, allowing reflection, making decisions, promoting communication, expression and creativity, among others. This is how sport should be appreciated as a generator of cognitive learning opportunities, values, attitudes and social actions.

So one of the challenges of education is to raise awareness and involve individuals so that they can actively participate in the decisions of their environment and for this it is necessary to have strategies that help them strengthen and promote their confidence in the development of different areas and spaces, Valencia (2008 p.1) indicates that:

\footnotetext{
"The new trends in Higher Education require a renewing educational practice to contribute to the integral formation of the graduate, thus harmonizing the formation of knowledge, habits, skills, and the construction of a life project based on values such as solidarity, social justice and human improvement"
} 
As the students advance in their educational formative stage, the brain develops functions that are manifested in the cognitive capacities, among which is the regulation of behavior, carrying out multi - task activities, among several others; Physical activity is part of the behaviors that will positively affect knowledge abilities and skills, according to studies, physical inactivity in children, sedentary lifestyle and poor performance in physical fitness are associated with lower academic performance ( Castelli, Hillman, Buck, \& Erwin, 2007; Chomitz et al., 2009).

Therefore, sport contributes to facilitating the various learning obstacles concerning other areas by developing intellectual abilities and capacities such as observation, understanding, analysis, reflection, perception, cooperation, socialization, participation, values, among others.

\section{Physical and Sports Activity in Cognitive Processes}

Animal studies have shown that physical activity (aerobic exercise) causes less neuronal degeneration, stimulating the molecular and cellular components of the brain (Neeper, Pinilla, Choi \& Cotman, 1996), part of the benefits obtained from performing it on a daily basis. , is that existing neurons are not lost as one ages (Larsen et al., 2000; Van Praag el al., 1999), because physical activity cooperates with the activation of brain areas in order to prevent diseases neurodegenerative, that over the years the intellectual capacities can be lost, so that exercising allows them to continue being maintained, since exercise positively affects the properties of the central nervous system to increase the capacity of the brain and counteract degenerative changes, there are studies that indicate that people with a higher cultural index, with a greater orientation to use their ability $d$ intellectual, have a lower probability of senile dementia (Stern et al., 1999).

A study carried out at the University of Illinois in 1999 showed that a group of volunteers who for 60 years led a sedentary life, after a routine consisting of a fast and continuous walk of 45 minutes three times a week, managed to improve their mental abilities. which are often lost with maturity, which indicates that exercise is linked to cognitive processes and abilities in humans.
Noting that there is a relationship between physical activity and the improvement of cognitive processes that have their origin in the brain and therefore academic performance in schools is positively affected, some authors mention that school performance is the product of the student expressed in school grades (Tilano, Henao \& Restrepo 2009), is also defined as the productivity of the individual, the final product of the application of their effort in activities, skills, attitudes and perceptions (León, 2008; Muela Martínez, García León, Augusto \& Lopez Zafra, 2010).

Scholars such as Brisswalter, Collardeu, Rene (2002), Lambourne \& Tomporowski, McMorris, Sproule, turner \& Hale (2010), Tomporowski, Lambourne \& Okumura (2011), have shown that people who do physical exercise at moderate intensity have a higher learning ability in cognitive areas such as selective attention, short-term memory and analysis, which indicates that the development and regular practice of physical exercise directly influences academic performance.

\section{Results}

The research carried out was carried out in an educational institution of upper middle level, which consists of a comparative analysis of young people who practice physical activity, exercise or sport and young people who lead sedentary lives; therefore, two groups were divided into the experiential group, which are those students who practice exercise, sport and physical activity but are also members of the school's sports groups and a second group called the control group made up of students who are totally sedentary.

A questionnaire was applied to them using the Likert scale and their grades were also accessed with the consent of the young people to verify the variable called academic performance.

\section{- Academic performance.}

For the present investigation we will understand as academic performance the evaluation of the knowledge, capacities, abilities, aptitudes and competences acquired in the school environment of the upper middle level, which are reflected in the student's grades.

From the sample taken we obtain that young people who do sports have a better academic performance with $92 \%$, than those who are sedentary with $64 \%$. Graphic 1 . 


\section{Academic record}

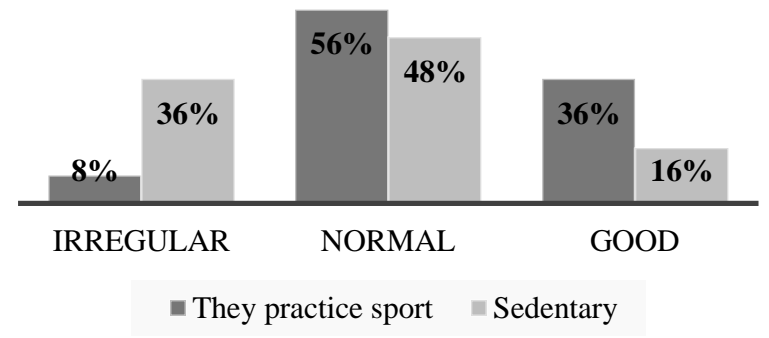

Graphic 1

Source: own source

So also, in graphic 1 , it is perceived that of every ten young people who carry out a physical activity and sport only one is irregular, while those who do not have the culture of sport the number increases to four irregular students.

- Participation.

Participation motivates to expose ideas and concerns, thereby achieving changes and developments in personal and social aspects in the community where individuals operate, which makes it an important factor of change in local spaces and in life of the population. According to the authors Werthein and Argumedo (1984), this element must be developed and assumed in order to change processes and transform realities to contribute to improving conditions and raising the quality of life of citizens.

Based on the above, we sought to observe the impact that sport has on the participation aspect, which is observed in graphic 2 .

\section{Participative in classes}

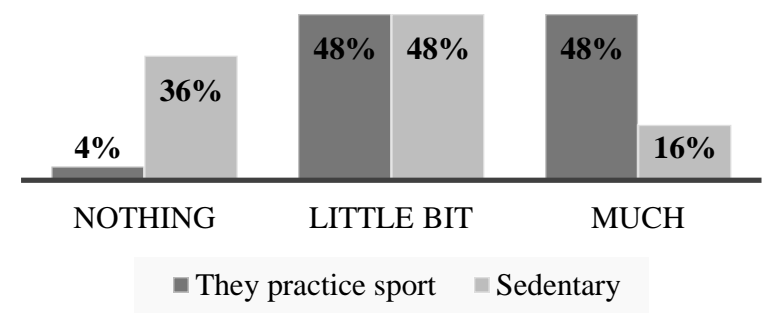

Graphic 2

Source: own source

According to the results obtained, there is a greater participation in class of students who do a sport with $96 \%$, while those who are sedentary only $64 \%$ of them participate, indicating that the sport influences significantly and positively by having a Greater confidence in expressing your opinions and concerns.
Contributing to participation fosters cooperation in decision-making, greater commitment to being factors of development, and gives the opportunity to expand knowledge and improve skills. (Robirosa, Cardarelli \& Lapalma, 1990), for which sport contributes to improving this element in students and responding to educational stimuli, expressing and formulating what has been learned in their training process.

- Decision making.

Graphic 3 exemplifies the development of the two sample groups (those who practice sports and sedentary), appreciating that despite having very similar figures, there is a difference of $8 \%$ in favor of those who perform physical activity but nevertheless not it is so representative.

From the analysis generated, it is found that of every ten students who exercise, only six identify and carry out the analysis of the possible alternatives and consequences of each one, assess them and compare their results and, based on this, issue a decision, while for those who do not do a sport are only five students who build it.

\section{Decision making}

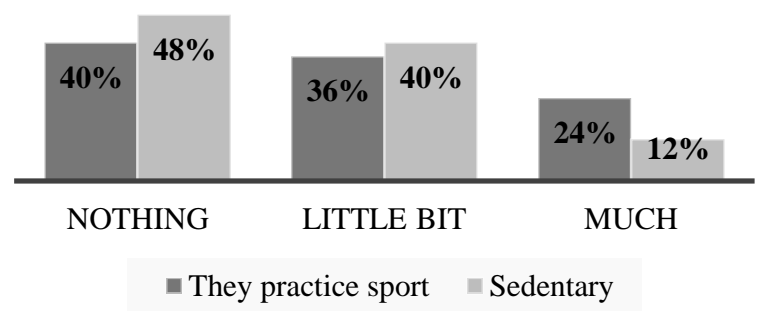

Graphic 3

Source: own source

- Handling.

Manipulation is an element that intervenes in the social interaction of the human being, which is inserted in the process of education of the individual, linking manipulative processes to shape behaviors (Yamamoto, 1995). In this research it is perceived as the exchange of ideas, ways of thinking and analyzing the problems of the environment between the same colleagues

In the following graphic it is distinguished that the students who practice sport are less manipulable by their peers when defending ideas, ways of thinking and analyzing the situations in the environment in which they operate and the realities of their region. 


\section{Manipulation by others}

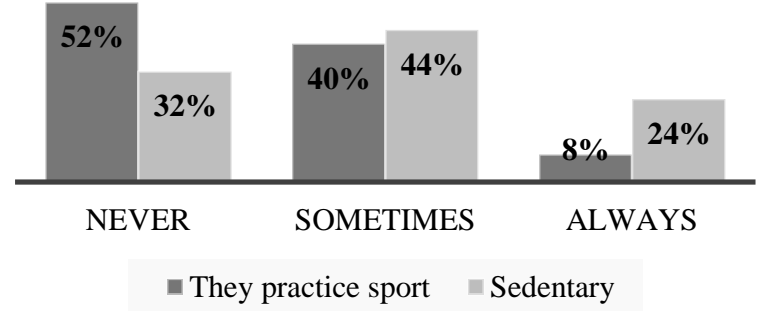

Graphic 4

Source: own source

For those who practice sport out of ten people, five of them are influenced, however, of these only four do it sporadically, that is, only one of them is continuously manipulable, however for sedentary students out of ten, seven are the ones that allow themselves to be influenced where only four do so occasionally, while three are always manipulable, which indicates that the more sedentary there is a greater probability of being manipulable.

\section{Conclusion}

It is perceived that there is a positive influence of sport on the cognitive processes of the student in academic performance, in this sense it is distinguished that through sport not only motor aspects are improved as traditionally seen, but also contributes to the development and improvement of cognitive areas such as participation and decision making.

Sport can be a generating instrument that contributes to the acquisition of social skills in individuals by strengthening confidence and thereby ensuring the defense of their ideas and points of view to solve problems that have to do with their local spaces, which allows have a greater social commitment to their environment.

The perception of the study determines that sports discipline can favor the specific development of cognitive functions in students.

\section{References}

Barbero González, J.I. (1993): "Introducción", en Brohm J.M. et al. (1993): Materiales de sociología del deporte, (J.I. Barbero González, comp.), pp. 9-38. La Piqueta. Madrid

Blázques, D. (1995). La iniciación deportiva y el deporte escolar. Barcelona, Inde

Brisswalter, J., Collardeau, M.. \& Rene A. (2002). Effects of acute physical exercise characteristics on cognitive performance. Sports Med. 32 (9), 555 - 566
Bordieu, P. (1993): "Deporte y clase social" (primera publicación en 1978), en Brohm J.M. et al. (1993): Materiales de sociología del deporte, pp. 57-82. (J.I. Barbero González, comp.) La Piqueta. Madrid.

Castelli, D., Hillman, C., Buck, S., \& Erwin, H. (2007). Physical fitness and academic achievement in third- and fifth-grade students. . Journal Sport Exercise Psychol , 239 -252.

Chomitz, V., Slining, M., McGowan, R., Mitchell, S., Dawson, G., \& Hacker, K. (2009). Is There a Relationship Between Physical Fitness and Academic Achievement? Positive Results From Public School Children in the Northeastern United States. Journal of School Health, 30-37.

Hernández D y Recoder G (2015). Historia de la Actividad Física y el Deporte. Bases conceptuales. Premisa Ordenadoras. Síntesis. Literatura. México

Elias, N. (1992): "Introducción", en Elias, N. y Dunning, E.: Deporte y ocio en el proceso de la civilización, pp. 31-82. Fondo de Cultura Económica. Madrid (ed. original en 1986).

Feu, G. (2000). Las actividades extraescolares en la escuela primaria. Una propuesta para llevar los programas de las Escuelas deportivas a los Centros Escolares. En Actas del I Congreso Nacional de Deporte en edad escolar, pp. 323 335. Dos Hermanas, Sevilla.

Hernandez Moreno, J. (1995). Análisis praxiológico de las estructuras de los deportes. En R.E.D. 2: 27-33.

León, B. (2008). Atención plena y rendimiento académico en estudiantes de enseñanza secundaria. European Journal of Education and Psychology.

Larsen JO, Skalicky M, Viidik A (2000) Does long-term physical exercise counteract agerelated Purkinje cell loss? A stereological study of rat cerebellum. J Comp Neurol 428: 213-222

Linder, K. (2002). The Physical Activity Participation Academic Performance Relationship Revisited: Perceived and Actual Performance and the Effect of Banding (Academic Tracking). Pediatric Exercise Science.

Mandell, R.D. (1986): Historia Cultural del Deporte. Bellaterra. Barcelona. 
McMorris, T., Sproule, J,. Turner A., \& Hale, B. J. (2011). A cute intermediate intensity exercise, and speed and accuracy in working memory task: Physiol Behav, 102 (3-4), 421 - 428

Muela, J. A., García-León, A., Augusto, J. M., y López-Zafra, E. (2010). La enseñanza de la Psicología a través de actividades desde una perspectiva multidisciplinar: aumento de la motivación y rendimiento. European journal of education and psychology.

Neeper SA, Gomez-Pinilla F, Choi J, Cotman CW (1996) Physical activity increases mRNA for brain-derived neurotrophic factor and nerve growth factor in rat brain. Brain Res 726: 49-56

Yamamoto (1995), El problema de la manipulación en la psicología aplicada. BITRA 22 Lima

Ramírez, W., Vinaccia, S., y Suárez, G. R. (2004). El impacto de la actividad física y el deporte sobre la salud, la cognición, la socialización y el rendimiento académico: una revisión teórica. Revista de estudios sociales.

Robirosa, M., Cardarelli, G. y A. Lapalma. (1990). Turbulencia y Planificación Social (Cap. I.)

Ruiz Llamas G, Cabrera Suárez D. Los valores en el deporte. Rev Educ. 2004; 335:9-19.

Sampedro J. (1996). Análisis praxiológico de los deportes de equipo. Una aplicación al futbol de sala. Tesis doctoral. Biblioteca INEF. Madrid

Stern Y, Albert S, Tang MX, Tsai WY (1999) Rate of memory decline in $\mathrm{AD}$ is related to education and occupation: cognitive reserve? Neurology 53: 1942-1947.

Tilano, L., Henao, G., y Restrepo, J. (2009). Prácticas educativas familiares y desempeño académico en adolescentes escolarizados en el grado noveno de instituciones educativas oficiales del municipio de Envigado.

Tomporowski, P.D (2003). Effects of a cute bouts of exercise on cognition. Acta Psychol (Amst). 112 (3) 297 - 324

Tomporowski, P.D. Lambourne, K., \& Okumura, M.S. (2011). Physical activity interventions and children's mental fuction: an introduction and overview. Prev Med, 52 Suppl 1, S3-9
Valencia, G. M. (2008). La importancia de la tutoría en el desarrollo integral del estudiante. Trabajo presentado en el 3er Encuentro Nacional de Tutoría, Puebla, México. Resumen recuperado de http://www.tutoria2008.buap.mx/file/conferenci as/67.pdf

van Praag H, Kempermann G, Gage FH (1999) Running increases cell proliferation and neurogenesis in the adult mouse dentate gyrus. Nat Neurosci 2: 266-270.

Werthein, J y Argumedo. M. (1984). "Elaboración curricular y aprendizaje colectivo en la educación participativa". IICA, MECSEPS. San José, Costa Rica. 